\title{
POSSIBILITIES OF MULTICULTURAL EDUCATION AT UNIVERSITIES IN SLOVAK REPUBLIC
}

\author{
[MOZNOSTI MULTIKULTURNEHO VZDELAVANIA NA \\ VYSOKYCH SKOLACH V SLOVENSKEJ REPUBLIKE]
}

\author{
Veronika Michvocikova
}

doi: 10.18355/PG.2019.8.1.4

\begin{abstract}
In today's society there is a growing contact of diverse cultures' members in the Slovakia territory and therefore each individual should have the basic knowledge necessary for life in the multicultural society. We consider participation in the educational process at all levels of the educational system in the Slovak republic as a significant way of acquiring knowledge for individuals. We focus on the educational process at universities in Slovakia. This process is connected with the need for the implementation of education in various areas. The presented article points out the education at the Slovak universities connected with multicultural education. For this reason, it is necessary to focus on the possibilities and ways of implementation and development of multicultural education in the universities educational process. We should clarify the attitudes and opinions of the university students that are connected with multicultural education. We should also map the ways of multicultural education supporting the realization of multicultural education by the view of university students. 200 university students attended an empirical survey. Data collection were based on the use of a pre-prepared questionnaire. Obtained data were processed and then the data were analyzed by using statistical software SPSS 20 in April 2016.
\end{abstract}

\section{Key words}

multicultural education, multicultural society, universities, university students

\begin{abstract}
Anotácia
V súčasnej spoločnosti dochádza k neustále narastajúcemu kontaktu príslušníkov rozmanitých kultúr už aj na území Slovenska. Každý jedinec by mal preto disponovat' základnými poznatkami potrebnými pre život v multikultúrnej spoločnosti. Za významný spôsob nadobúdania poznatkov u jednotlivcov považujeme participáciu na edukačnom procese na všetkých úrovniach vzdelávacieho systému v Slovenskej republike. Centrum pozornosti predkladaného článku smeruje kedukačnému procesu na vysokých školách na Slovensku v súvislosti s potrebou realizovania multikultúrneho vzdelávania. Z tohto dôvodu je potrebné zamerat' sa na zmapovanie možností a spôsobov, prostredníctvom ktorých je možné realizovat' a rozvíjat' multikultúrne vzdelávanie v edukačnom procese vysokých škôl na Slovensku. Na priblíženie nastolenej problematiky je možné poukázat' aj na základe postojov a názorov oslovených
\end{abstract}


vysokoškolských študentov v rámci realizovaného prieskumu v apríli v rok 2016.

Empirického prieskumu sa zúčastnilo 200 vysokoškolských študentov. Získavanie údajov prebiehalo na základe využitia vopred pripraveného dotazníka. Získané údaje boli spracované, a následne analyzované prostredníctvom štatistického softvéru SPSS 20.

\section{Kl’účové slová}

multikultúrna spoločnost', multikultúrne vzdelávanie, vysoké školy, vysokoškolskí študenti

\section{Úvod}

Edukácia predstavuje nezanedbatel'nú súčast' života každého človeka. Svojou elementárnou podstatou spravidla smeruje k vzdelávaniu a vychovávaniu jedincov. Participáciou na edukácii sa vzdelávaný a vychovávaný človek začleňuje do každodenného kolobehu života. Z tohto dôvodu sa aj obsah a spôsob edukácie do vel'kej miery prispôsobuje javom a procesom v spoločnosti. Ked’že sa v súčasnosti stretávame s problematikou existencie multikultúrnej spoločnosti, tak spomínaný aspekt sa bez najmenších pochybností odzrkadl'uje aj vedukácii. Multikulturalizmus determinujúci fungovanie multikultúrnej spoločnosti zahŕňa podstatu spolunažívania príslušníkov rozmanitých kultúr, rás, etník či národov. Preto je potrebné práve v rámci výchovy a vzdelávania obsiahnut' čo možno najefektívnejším spôsobom vysvetlenie multikulturalizmu a problematiky multikultúrnej spoločnosti. Dôležitými sa stávajú najmä možnosti a spôsoby, na základe ktorých sú jedinci $\mathrm{v}$ rámci edukačného procesu oboznamovaní s vyššie uvedeným obsahom výchovy a vzdelávania, a to prostredníctvom participácie na multikultúrnej výchove realizovanej v edukačnom procese v slovenskom školstve. Všetky úrovne vzdelávacieho systému si vyžadujú postupné načrtnutie konceptualizácie multikultúrnej spoločnosti v súčasnosti. Centrum pozornosti predkladaného článku však smeruje kedukačnému procesu na vysokých školách. Multikultúrna výchova uskutočňovaná vo vysokoškolskej edukácii sa nezanedbatel'ným spôsobom podiel'a na formovaní osobnosti vysokoškolských študentov. Vysokoškoláci sa oboznamujú so špecifikami typickými pre príslušníkov iných kultúr, etník, rás alebo národov. Práve rozmanité spôsoby nadobúdania poznatkov a informácií o spomenutých špecifikách považujeme za nevyhnutný predpoklad eliminovania strachu z doposial' neznámych hodnôt noriem či zaužívaných spôsobov správania sa a konania minoritných skupín obyvatel'stva. Taktiež je na jednej strane dôležité, aby bola multikultúrna výchova prítomná v učebných osnovách na všetkých úrovniach vzdelávacieho systému v Slovenskej republike. Na strane druhej však upozorňujeme na nevyhnutnost' multikultúrneho vzdelávania práve na vysokých školách. Vysokoškolskí študenti predstavujú v súčasnosti početnú skupinu obyvatel'stva, a je dôležité, aby disponovali minimálne základnými informáciami o podstate spolunažívania viacerých skupín obyvatel'stva. Z tohto dôvodu sa zaujímame o to, akým spôsobom je možné realizovat' multikultúrnu výchovu v rámci edukačného procesu na vysokých školách v Slovenskej republike. 


\section{Multikultúrna spoločnost'}

\section{Formovanie multikultúrnej spoločnosti na území Slovenskej republiky}

Multikultúrna spoločnost' je v súčasnosti vel'mi diskutovanou témou v mnohých spoločenských oblastiach. V multikultúrnej spoločnosti môžu koexistovat' rozmanité národy vyznačujúce sa heterogénnou kultúrou (Poláková, 2001, s. 11). Pre potreby zamerania nášho príspevku je dôležité, aby sme charakterizovali multikultúrnu spoločnost' ako spoločnost', v ktorej je možné spolunažívanie príslušníkov viacerých kultúr. Každá z daných kultúr si pritom zachováva a udržiava svoje tradície, hodnoty a normy. Rovnako treba zdôraznit', že jednotlivé kultúry obývajúce konkrétne teritórium sa dokážu rešpektovat'. Ak sa zameriavame na existenciu multikultúrnej spoločnosti na Slovensku, sústred'ujeme pozornost' smerom k stručnému historickému exkurzu do danej problematiky. Počiatky prelínania a kontakt rôznych kultúr pozorujeme na území súčasnej Slovenskej republiky už od počiatkov existencie l'udstva. Podl'a Mistríka hovoríme o území Slovenska ako o križovatke kultúr z nasledujúcich dôvodov (Mistrík a kol., 2008, s. 10-11):

a) Osídlovanie územia Slovenska už od obdobia praveku (predovšetkým územie Bratislavy, Nitry, Spišu či Považia),

b) Kontakt s Rímskou ríšou (stret obchodných ciest),

c) Postupné osídlovanie spomínaného územia Židmi,

d) Príchod Slovanom na územie súčasnej Slovenskej republiky a neustály spravidla ozbrojený konflikt s Avarmi

e) Kristianizácia územia spojená s príchodom Konštantína a Metoda z Byzantskej ríše,

f) Expanzia Mad'arov na územie Karpatskej kotliny, postupné formovanie Uhorského štátu spojené s mad'arizáciou obyvatel'stva,

g) Príchod Nemcov, Rómov a valachov z Rumunska na územie dnešnej Slovenskej republiky,

h) Vplyv pol'skej kultúry a kultúry goralov,

i) Postupné pôsobenie učitel'ov, umelcov, kňazov, a to predovšetkým z Rakúska, Česka, Talianska, Ruska.

j) Silný vplyv ruskej kultúry, a to hlavne vobdobí existencie komunistického Československa.

Na základe vyššie načrtnutých procesov spojených s prelínaním a vplyvom jednotlivých kultúr na území Slovenska súhlasíme s ponímaním uvedeného územia ako križovatky rozmanitých kultúr. Podl'a nášho názoru je však zároveň dôležité doplnit' stručný obraz aktuálnej situácie na území Slovenskej republiky, kedy dochádza k neustálemu, viac či menej intenzívnemu kontaktu príslušníkov viacerých kultúr, a to predovšetkým prostredníctvom priebehu procesu globalizácie. „Globalizácia ekonomického života, mediálneho pôsobenia i politických rozhodnutí a vojenských konfliktov od 20. storočia spôsobuje, že na Slovensku cítime dôsledky akýchkol'vek globálnych aktivít, napr. prist'ahovanie množstva Vietnamcov, Arabov a príslušníkov iných národov ako súčast' pomoci bývalého komunistického Československa, migrácia Albáncov, Afgáncov a d'alších vplyvom lokálnych vojenských konfliktov.“ (Mistrík a kol., 2008, s. 11) 
Globalizáciu považujeme za významný proces ovplyvňujúci celkový charakter základných spoločenských vzt'ahov a procesov. Neustále sa rozširujúca prepojenost' sa prejavuje aj v oblasti kultúry. Príslušníci národov prestávajú byt' viazaní na konkrétne teritoriálne územie. Pod vplyvom rôznych okolností opúšt’ajú svoje pôvodné domovy pričom hl'adajú alternatívne možnosti svojej každodennej existencie. V mnohých prípadoch prekonávajú nemalé vzdialenosti a ocitnú sa v krajinách, kde sú hodnoty a normy ich kultúry neznáme pre príslušníkov väčšinových kultúr. Z tohto dôvodu prichádzajú v poslednom období aj Slováci do kontaktu $\mathrm{s}$ príslušníkmi iných národov ovel'a viac ako v minulosti. Mistrík poukazuje predovšetkým na migráciu Vietnamcov, Číňanov či obyvatel'ov bývalého Sovietskeho zväzu (Ukrajincov, Rusov, Kazachov) na Slovensko (Mistrík a kol., 2008, s. 11). Na jednej strane súhlasíme s vyššie uvedeným autorom, nakol'ko na Slovensku bezpochybne narastá počet príslušníkov spomínaných národov. Na druhej strane však nesmieme zabúdat' ani na migračnú krízu v súčasnej spoločnosti, na základe ktorej sa v európskych krajinách zvyšuje najmä podiel obyvatel'stva z moslimských krajín či krajín Blízkeho východu vyznačujúcich sa pretrvávajúcim vojenským konfliktom nútiacim obyvatel'stvo migrovat' do ekonomicky a bezpečnostne stabilnejších krajín. Preto je aj interakcia príslušníkov rozmanitých kultúr podstatne častejšia v porovnaní s minulost'ou. Bezproblémový priebeh spoločenských interakcií medzi príslušníkmi rozmanitých kultúr je podl'a nášho názoru možný jedine na základe dôkladného a dôsledného poznania daných kultúr, ich hodnôt a noriem. Za vhodný spôsob poznávania hodnôt a noriem kultúr odlišných od väčšinovej kultúry považujeme vzdelávanie jedincov v rámci edukačného procesu na všetkých úrovniach vzdelávacieho systému v Slovenskej republike. Vzdelávaní jedinci by mali participovat' na multikultúrnej výchove zahŕňajúcej výstižné a efektívne oboznámenie sa s existenciou človeka v multikultúrnej spoločnosti.

\section{Multikultúrna výchova}

Ak sa chceme zaoberat' vymedzením spôsobov a možností realizácie multikultúrnej výchovy, musíme v prvom rade sústredit' centrum našej pozornosti smerom k vychovávaniu jedincov. Výchovu nemôžeme vnímat' iba ako manipulatívny a ovplyvňujúci proces. Práve naopak, hovoríme o sprostredkovaní návykov, z ktorých vyplýva interakcia jednotlivcov, skupín a národov (Dvoranová, 2010, s. 372). Na tomto mieste zdôrazn̆ujeme ponímanie výchovy ako zámerného procesu podmieňujúceho formovanie individuálnych vlastností jedinca potrebných pre priebeh základných spoločenských interakcií. Prostredníctvom výchovy sa jedinec oboznamuje s všeobecne uznávanými hodnotami a normami v spoločnosti, na základe ktorých dokáže uskutočňovat' interakcie s ostatnými jedincami či spoločenskými skupinami.

Vo všeobecnosti teda môžeme výchovu chápat' podl'a Kudláčovej ako (Kudláčová, 2007, s. 170):

1) Výhradne l'udská záležitost' s dôrazom na vedomé rozvíjanie l'udskej osobnosti

2) Integrálna funkcia v živote l'udstva 
3) Pozitívna vo vzt’ahu k človeku a životu

4) Obsahuje zámernost' a ciel'avedomost'

Za najdôležitejšiu charakteristiku výchovy považujeme hlavne vedomé rozvíjanie l'udskej osobnosti. Uvedomelost' konania je výhradne l'udskou vlastnostou, ktorá sa prenáša aj do vychovávania l'udských jedincov. Vedomé rozvíjanie osobnosti človeka prostredníctvom výchovy je determinované celkovým charakterom usporiadania elementárnych spoločenských interakcií. Opätovne musíme zdôraznit', že priebeh interakcií v spoločnosti závisí od aktuálnych javov a procesov utvárajúcich celkový obraz vzt’ahov a procesov nevyhnutných pre prežívanie každodenného života človeka. Na základe priebehu procesu výchovy dochádza $\mathrm{k}$ viac či menej úplnému začleňovaniu vychovávaných jedincov nielen do celej spoločnosti ale aj do jednotlivých spoločenských skupín. Podl'a nášho názoru je dôležité, aby výchova okrem integračnej funkcie odovzdávala l'ud'om prevažne kladné ponímanie života, ako aj všetkého čo je spojené s prežívaním každodennosti. Rovnako chceme zdôraznit', že ak chápeme výchovu ako ciel'avedomú činnost' l'udských jedincov, tak za jej všeobecný ciel' považujeme formovanie ideálneho typu človeka v spoločnosti (Turek, 1998, s. 25). Prostredníctvom realizácie rozmanitých výchovných spôsobov dochádza k zámernému formovaniu osobnosti vychovávaného jedinca, a to na základe akceptovania a dodržiavania všeobecne ustálených a zaužívaných spôsobov správania sa a konania.

\section{Multikultúrne vzdelávanie na slovenských vysokých školách}

Vysokoškolská edukácia smeruje k celkovému rozvoju osobnosti vychovávaných a vzdelávaných osôb - mladých l'udí, ktorí si participáciou na uvedenom procese neustále formujú svoje postoje a názory prepojené $\mathrm{s}$ rozmanitou problematikou odzrkadl'ujúcou aj aktuálne dianie $\mathrm{v}$ súčasnej spoločnosti. Zdôraznením načrtnutých teoretických východísk spojených s problematikou multikultúrnej spoločnosti je nevyhnutné, aby bola súčastou edukačného procesu na vysokých školách multikultúrna výchova. Musíme si teda položit' otázku, akým spôsobom by mala byt' multikultúrna výchova realizovaná. Podl'a nášho názoru by malo byt' multikultúrne vzdelávanie vysokoškolákov spojené predovšetkým $\mathrm{s}$ aktívnym prístupom vysokoškolského pedagóga. Aktívny prístup vysokoškolského pedagóga by mal spočívat' hlavne $\mathrm{v}$ aktívnom diskutovaní so študentmi o problematike multikulturalizmu, ako aj multikultúrnej spoločnosti. V tomto kontexte študenti nadobúdajú prirodzeným spôsobom základné informácie, ako aj poznatky prepojené s poznávaním príslušníkom iných kultúr, rás etník či národov. U mladého človeka dochádza k eliminovaniu strachu či obavy z doposial' neznámych hodnôt, noriem, tradícií a spôsobov správania sa či konania u príslušníkov menšín žijúcich na území obývanom majoritou. Aktívnu komunikáciu, a teda diskusiu vyučujúceho so svojimi študentmi považujeme za najvýznamnejšiu a najefektívnejšiu možnost' multikultúrnej výchovy v edukačnom procese vysokých škôl na Slovensku. V rámci nášho prieskumu sme oslovili 200 vysokoškolských študentov študujúcich na vysokých školách v Slovenskej republike a zist'ovali sme, či majú možnost' aktívne diskutovat' o problematike multikultúrnej spoločnosti $\mathrm{v}$ rámci 
prednášok a seminárov. Získané údaje boli prehl'adne zaznamenané do nasledujúcej tabul'ky (tabul'ka 1).

Tabul'ka 1 Diskusia zameraná na multikultúrnu spoločnost' počas prednášok a seminárov

\begin{tabular}{|l|r|r|}
\hline $\begin{array}{l}\text { Diskusia zameraná na multikultúrnu } \\
\text { spoločnost' počas prednášok a seminárov }\end{array}$ & Početnost' & $\%$ \\
\hline neodpovedal & 15 & 7,8 \\
\hline nie & 28 & 14,5 \\
\hline skôr nie & 37 & 19,2 \\
\hline skôr áno & $\mathbf{4 5}$ & $\mathbf{2 3 , 3}$ \\
\hline áno & $\mathbf{4 7}$ & $\mathbf{2 4 , 4}$ \\
\hline neviem posúdit' & 21 & 10,9 \\
\hline spolu & 193 & 100,0 \\
\hline
\end{tabular}

$\mathrm{Na}$ základe údajov vo vyššie uvedenej tabul'ke (tabul'ka 1) môžeme skonštatovat', že oslovení vysokoškolskí študenti sa v rámci svojej participácie na vysokoškolskom edukačnom procese stretávajú s diskutovaním o problematike multikultúrnej spoločnosti na prednáškach a seminároch. Približne $24 \%$ opýtaných jednoznačne vyjadrilo, že má možnost' aktívne sa zapájat' do diskusie zameranej na problematiku multikultúrnej spoločnosti. Taktiež treba doplnit', že približne rovnaký počet respondentov sa priklonil k možnosti, že skôr má ako nemá možnost' v rámci prednášok a seminárov diskutovat' na uvedenú problematiku. $\mathrm{Na}$ druhej strane podotkneme, že iba približne $15 \%$ opýtaných nemá možnost' diskutovat' o problematike multikultúrnej spoločnosti na prednáškach a seminároch. Musíme opätovne zdôraznit', že aktívna diskusia nielen vysokoškolského pedagóga so študentmi, ale aj diskusia medzi študentmi navzájom napomáha keliminovaniu prípadných predsudkov voči odlišnostiam.

Ak považujeme diskusiu spojenú s problematikou multikultúrnej spoločnosti na prednáškach a seminároch za významný spôsob multikultúrnej výchovy, je potrebné skúmat', do akej miery sú diskutovaním o problematike multikultúrnej spoločnosti počas priebehu vysokoškolského edukačného procesu determinované postoje a názory opýtaných vysokoškolských študentov prepojené s potrebou vytvárania podmienok pre bezkonfliktné spolunažívanie Slovákov a príslušníkov menšín žijúcich na území Slovenskej republiky. Výsledky druhostupňového triedenia údajov sú zaznamenané v nasledujúcej tabul'ke (tabul'ka 2).

Tabul'ka 2 Diskusia zameraná na multikultúrnu spoločnost' počas prednášok a seminárov a Vytváranie podmienok pre bezkonfliktné spolunažívanie Slovákov a príslušníkov menšín žijúcich na území Slovenskej republiky 


\begin{tabular}{|c|c|c|c|c|c|c|c|c|}
\hline \multirow{2}{*}{\multicolumn{2}{|c|}{$\begin{array}{l}\text { Diskusia } \\
\text { zameraná na } \\
\text { multikultúrnu } \\
\text { spoločnost' počas } \\
\text { prednášok a } \\
\text { seminárov }\end{array}$}} & \multicolumn{7}{|c|}{$\begin{array}{l}\text { Vytváranie podmienok pre bezkonfliktné } \\
\text { spolunažívanie Slovákov a príslušníkov menšín } \\
\text { žijúcich na území Slovenskej republiky }\end{array}$} \\
\hline & & \multirow{2}{*}{$\begin{array}{l}\text { chýba } \\
\text { odpoved' } \\
0 \\
\end{array}$} & \multirow{2}{*}{$\begin{array}{r}\text { nie } \\
\\
1 \\
\end{array}$} & \multirow{2}{*}{$\begin{array}{r}\begin{array}{l}\text { skôr } \\
\text { nie }\end{array} \\
5 \\
\end{array}$} & \multirow{2}{*}{\begin{tabular}{|r|} 
skôr \\
áno \\
3 \\
\end{tabular}} & \multirow{2}{*}{$\begin{array}{r}\text { áno } \\
\\
1 \\
\end{array}$} & \multirow{2}{*}{\begin{tabular}{|r|}
$\begin{array}{l}\text { neviem } \\
\text { posúdit' }\end{array}$ \\
5 \\
\end{tabular}} & \multirow{2}{*}{\begin{tabular}{|r|} 
spolu \\
15 \\
\end{tabular}} \\
\hline chýba & počet & & & & & & & \\
\hline odpoved' & $\%$ & 0,0 & 0,5 & 2,6 & 1,6 & 0,5 & 2,6 & 7,8 \\
\hline \multirow{2}{*}{ nie } & počet & 1 & 3 & 9 & 4 & 8 & 3 & 28 \\
\hline & $\%$ & 0,5 & 1,6 & 4,7 & 2,1 & 4,1 & 1,6 & 14,5 \\
\hline \multirow{2}{*}{ skôr nie } & počet & 7 & 3 & 7 & 6 & 7 & 7 & 37 \\
\hline & $\%$ & 3,6 & 1,6 & 3,6 & 3,1 & 3,6 & 3,6 & 19,2 \\
\hline \multirow{2}{*}{ skôr áno } & počet & 1 & 10 & 17 & 6 & 4 & 7 & 45 \\
\hline & $\%$ & 0,5 & 5,2 & 8,8 & 3,1 & 2,1 & 3,6 & 23,3 \\
\hline \multirow{2}{*}{ áno } & počet & 4 & 8 & 16 & 4 & 8 & 7 & 47 \\
\hline & $\%$ & 2,1 & 4,1 & 8,3 & 2,1 & 4,1 & 3,6 & 24,4 \\
\hline \multirow{2}{*}{$\begin{array}{l}\text { neviem } \\
\text { posúdit' }\end{array}$} & počet & 2 & 3 & 9 & 3 & 2 & 2 & 21 \\
\hline & $\%$ & 1,0 & 1,6 & 4,7 & 1,6 & 1,0 & 1,0 & 10,9 \\
\hline \multirow{2}{*}{ spolu } & počet & 15 & 28 & 63 & 26 & 30 & 31 & 193 \\
\hline & $\%$ & 7,8 & 14,5 & 32,6 & 13,5 & 15,5 & 15,5 & 100,0 \\
\hline
\end{tabular}

Druhostupňovým triedením údajov prostredníctvom štatistického softvéru SPSS 20 môžeme skonštatovat', že diskusia na prednáškach a seminároch spojená s problematikou multikultúrnej spoločnosti nepodmieňuje u oslovených vysokoškolákov postoje a názory v súvislosti s vytváraním bezkonfliktného spolunažívania Slovákov a príslušníkov iných kultúr na území Slovenskej republiky. Uvedené zistenie môžeme odôvodnit' skutočnost'ou, že aj napriek multikultúrnej výchove mladí l'udia nie sú zatial' pripravení akceptovat' odlišné hodnoty a normy, a zároveň si nevedia predstavit' svoj každodenný život a každodenný neustály kontakt s príslušníkmi odlišných kultúr.

\section{Diskusia}

Multikultúrna spoločnost' predstavuje podl'a nášho názoru nezanedbatel'nú súčast' každodenných interakcií jednotlivcov. Rovnako aj územie Slovenskej republiky nie je výnimkou, a preto je potrebné, aby boli jedinci pripravení na uskutočňovanie interakcií aj na základe kontaktu s príslušníkmi minoritných kultúr. Z tohto dôvodu nachádza tematika multikultúrnej spoločnosti svoje zaradenie aj $\mathrm{v}$ edukačnom procese realizovanom na vysokých školách. Multikultúrna spoločnost' je témou, ktorá sa postupne stáva reflektovanou aj počas vysokoškolských prednášok a seminárov. Mladí l'udia študujúci na vysokej škole môžu na danú tematiku komunikovat' s vysokoškolským pedagógom, ako aj s ostatnými vysokoškolskými študentmi. Prichádzajú tak do kontaktu s rozmanitými postojmi a názormi prepojenými s uvedenou oblast'ou. Prostredníctvom daného spôsobu oboznamovania sa $\mathrm{s}$ 
problematikou mulitkulturalizmu si vysokoškolskí študenti môžu formovat' svoje vlastné postoje a názory. Avšak na druhej strane treba poznamenat', že tematizovanie multikultúrnej spoločnosti počas prednášok a seminárov nedeterminuje u oslovených mladých l'udí - vysokoškolských študentov potrebu vytvorenia podmienok pre bezkonfliktné spolunažívanie Slovákov a príslušníkov menšín, ktoré žijú na území Slovenskej republiky. Na jednej strane sú mladí l'udia v súčasnosti flexibilní, rýchlo sa dokážu pripôsobovat' zmenám, a rovnako ani inovácie $\mathrm{v}$ mnohých oblastiach nepredstavujú pre uvedenú spoločenskú skupinu problematický jav. Nesmieme však zabudnút' zdôraznit', že práve na základe celkového obrazu súčasného sveta majú mladí l'udia, rovnako teda aj vysokoškolskí študenti obavu z neustáleho prelínania jednotlivých kultúrných odlišností, ako aj z kontaktu s príslušníkmi kultúr odlišujúcich sa od toho, čo je zaužívané na území Slovenskej republiky. Ani prednášky a semináre vysokoškolskej výučby zatial' nedokážu eliminovat' uvedené obavy slovenských študentov študujúcich na vysokých školách. Mladý človek potrebuje mat' istotu v svojej budúcnosti, potrebuje sa niekam zaradit', niekam patrit'. Práve preto je príslušnost' $\mathrm{k}$ slovenskému národu pre mladých l'udí, konkrétne aj pre vysokoškolských l'udí potrebnou istotou existencie do budúcnosti. Inovácie, a hlavne kultúrne odlišnosti by sa podla postojov a názorov mladých l'udí mohli podiel'at' na postupnom zániku či asimilácii národa Slovákov. Podl’a nášho názoru sa vysokoškoláci na Slovensku bez ohl'adu na to, čo sa dozvedajú na prednáškach či seminároch nedokážu zbavit' obáv zo straty suverenity či samostatnosti národa Slovákov hlavne na základe súčasného diania $\mathrm{v}$ jednotlivých európskych aj svetových krajinách.

\section{Záver}

$\mathrm{V}$ predkladanom článku sme sa zaoberali načrtnutím problematiky multikultúrnej spoločnosti $\mathrm{v}$ súčasnosti. Multikulturalizmus je $\mathrm{v}$ uplynulých rokoch diskutovanou témou. $\mathrm{Z}$ tohto dôvodu je potrebné, aby mali jedinci možnost' sa bližšie oboznámit' $\mathrm{s}$ tým, ako prežit' plnohodnotný a bezproblémový každodenný život $\mathrm{v}$ multikultúrnej spoločnosti. Ked’že aj na území Slovenskej republiky dochádza ku kontaktu príslušníkov rozmanitých kultúr, etík rás a národov, musíme hlavne vo vychovávaní a vzdelávaní jedincov smerovat' proces formovania osobnosti $k$ tolerancii a rešpektovaniu a tolerancii kultúrnych odlišností. Výchova a vzdelávanie jedincov sa uskutočňuje $\mathrm{v}$ rámci participácie na edukačnom procese na všetkých úrovniach vzdelávacieho systému v Slovenskej republike. Centrum našej pozornosti sme sústredili smerom $\mathrm{k}$ vysokoškolskému edukačnému procesu a ku konceptualizácii multikultúrnej výchovy. Za najefektívnejší spôsob multikultúrneho vzdelávania jedincov $\mathrm{v}$ rámci edukačného procesu na vysokej škole považujeme diskutovanie o existencii odlišností predovšetkým v rôznych kultúrach. Priebeh diskusie o problematike existencie multikultúrnej spoločnosti by mal byt založený na aktívnej interakcii vysokoškolského pedagóga so študentmi. $\mathrm{V}$ rámci nášho prieskumu sme oslovili 200 vysokoškolských študentov študujúcich na vysokých školách na Slovensku. Oslovení vysokoškoláci majú $\mathrm{v}$ rámci prednášok a seminárov možnost' aktívneho zapojenia sa do diskusie na danú problematiku. Na druhej 
strane však treba zdôraznit', že ani tematizovanie multikultúrnej spoločnosti v rámci vysokoškolskej edukácie nedeterminuje bezproblémovejšie ponímanie príslušníkov iných kultúr na Slovensku z pohl’adu opýtaných vysokoškolských študentov.

Skúmaná tematika otvára široký priestor pre d’alšie skúmanie. V súvislosti $\mathrm{s}$ načrtnutými zisteniami je potrebné venovat' zvýšenú pozornost' možnostiam, na základe ktorých by vysokoškolskí študenti podrobnejšie a dôslednejšie mohli poznávat' hodnoty, normy a spôsoby správania sa a konania príslušníkov minoritných kultúr, etník, rás a národov žijúcich na území Slovenskej republiky. Taktiež je dôležité nezabúdat' ani na komplexnejšie preskúmanie prístupu vysokoškolských pedagógov $\mathrm{k}$ vyučovaniu multikultúrnej výchovy.

\section{Bibliographic references}

DVORANOVA, E. 2010. Co je vychova? Niekolko poznamok k filozofii vychovy. In Filozofia roc 65 c 4 s 371 - 377. ISSN 0046-385X.

KOMINAREC, I. - KOMINARCOVA, E. 2005. Multikulturalita a edukacia. Presov: Grafotlac. ISBN 80-8068-380-8.

KUDLACOVA, B. 2007. Clovek a vychova v dejinach europskeho myslenia. Trnava: Pedagogicka fakulta Trnavskej univerzity. ISBN 80-80821-20-3.

MISTRIK, E. a kol. 2008. Multikulturna vychova v skole. Ako reagovat na kulturnu roznorodost. Bratislava: Nadacia otvorenej spolocnosti. ISBN 97880-969271-4-2.

POLAKOVA, E. 2001. Prostriedky masovej komunikacie, multikulturna spolocnost a vzdelavanie. Nitra: UKF. ISBN 978-80-805-0396-3

TUREK, I. 1998. Zvysovanie efektivnosti vyucovania. Bratislava: EDUKACIA. ISBN 80-88796-89-X.

Mgr. Veronika Michvocíková, PhD.

Department of Pedagogy

Faculty of Arts

University of Ss. Cyril and Methodius

Nám. J Herdu 2

91701 Trnava

Slovakia

veronika.michvocikova@ucm.sk 